\title{
Enzymatic synthesis of tryptamine and its halogen derivatives selectively labeled with hydrogen isotopes
}

\author{
Sylwia Dragulska • Marianna Kańska
}

Received: 5 August 2013/Published online: 10 November 2013

(c) The Author(s) 2013. This article is published with open access at Springerlink.com

\begin{abstract}
Nine isotopomers of tryptamine and its halogen derivatives, labeled with deuterium, tritium in side chain, i.e., $\left[(1 R)-{ }^{2} \mathrm{H}\right]-,\left[(1 R)-{ }^{3} \mathrm{H}\right]-$, 5-F-[(1R)- $\left.{ }^{2} \mathrm{H}\right]-$, 5-F-[(1R)- $\left.{ }^{3} \mathrm{H}\right]-$, $5-\mathrm{Br}-\left[(1 R)-{ }^{2} \mathrm{H}\right]-$, double labeled $\left[(1 R)_{-}{ }^{2} \mathrm{H} /{ }^{3} \mathrm{H}\right]-, \quad 5-\mathrm{F}-$ $\left[(1 R)-{ }^{2} \mathrm{H} /{ }^{3} \mathrm{H}\right]-$, and ring labeled $\left[4{ }^{2} \mathrm{H}\right]-$, and $\left[5{ }^{2} \mathrm{H}\right]$-tryptamine, were obtained by enzymatic decarboxylation of L-Trp and its appropriate derivatives in deuteriated or tritiated media, respectively. Intermediates: $\left[5^{\prime}-{ }^{2} \mathrm{H}\right]-\mathrm{L}-\mathrm{Trp}$ used for further decarboxylation was synthesized by enzymatic coupling of $\left[5{ }^{2} \mathrm{H}\right]$-indole with $S$-methyl-L-cysteine, and $\left[4^{\prime}-{ }^{2} \mathrm{H}\right]-\mathrm{L}-\mathrm{Trp}$ was obtained by isotope exchange ${ }^{1} \mathrm{H} /{ }^{2} \mathrm{H}$ of the authentic L-Trp dissolved in heavy water induced by UV-irradiation. Doubly labeled $\left[(1 R){ }_{-}^{2} \mathrm{H} /{ }^{3} \mathrm{H}\right]$ and $5-\mathrm{F}-\left[(1 R)-{ }^{2} \mathrm{H} /{ }^{3} \mathrm{H}\right]$-tryptamine were obtain by decarboxylation of L-Trp or [5'-F]-L-Trp carried out in ${ }^{2} \mathrm{H}^{3} \mathrm{HO}$ incubation medium.
\end{abstract}

Keywords Decarboxylation · Deuterium ·

L-Phenylalanine decarboxylase $\cdot$ Tritium ·

Tryptamine derivatives $\cdot$ Tryptamine

\section{Introduction}

Tryptamine, a biogenic amine is also the backbone for a group of compounds known collectively as tryptamines. This group includes many biologically active, natural or

S. Dragulska · M. Kańska ( $₫)$

Department of Chemistry, University of Warsaw, Pasteur Str. 1, 02-093 Warsaw, Poland

e-mail: mkanska@chem.uw.edu.pl

M. Kańska

Medical University of Warsaw, Żwirki i Wigury Str. 61, 02-091 Warsaw, Poland synthetic compounds, including neurotransmitters, e.g., serotonin, melatonin $[1,2]$ and psychedelic drugs such as DMT ( N,N-dimethyltryptamine) [3, 4], and psilocybin. Diversity of tryptamine derivatives due to the large number of substituents in the different positions of the indole ring and the aliphatic chain, therefore, this class of compounds has been widely used in medicinal chemistry for production the psychoactive drugs. The tryptamines have a multiple applications: they regulate many biologically processes, affect the nervous system (serotonin) [5], and are involved in the sleep-wake cycle (melatonin) [2].

In mammals brain tryptamine, acting as an endogenous neurotransmitter, is synthesized by the enzymatic decarboxylation of L-tryptophan (L-Trp) catalyzed by aromatic L-amino acid decarboxylase [AADC (EC 4.1.1.28)], and is metabolized to 3-indolcetaldehyde (3-IAL) by oxidative deamination catalyzed by the enzyme monoamine oxidase (MAO, EC 1.4.3.4) [6] (Fig. 1).

In the plants and mammalian the bioamines, products of enzymatic decarboxylation of amino acids play a role of precursors of a wide range of alkaloids and other biologically active compounds [7]. The enzyme aromatic L-ADDC (EC 4.1.1.28), involved in production of tryptamine [8] is also an effective catalyst in the decarboxylation of various aromatic L-amino acids 3,4-dihydroxy-L-phenylalanine (L-DOPA), L-tryptophan, 5'-hydroxy-L-tryptophan, phenyl-L-alanine, L-tyrosine, and L-histidine [9]. This pyridoxal phosphate (PLP) containing enzyme is widely distributed in mammalian tissues and is responsible for the production of indolamines (serotonin, melatonin), and catecholamines (dopamine, adrenaline, and noradrenaline) [10]. The enzyme AADC is found in serum of various animals such as guinea pig, rat, monkey, mice and humans. Catecholaminergic and serotonergic cells such as adrenal glands, brain, and other tissues as liver and kidney are rich in this enzyme [11]. 
Fig. 1 The metabolic pathway of L-Trp to 3-indolacetaldehyde, 3-IAL

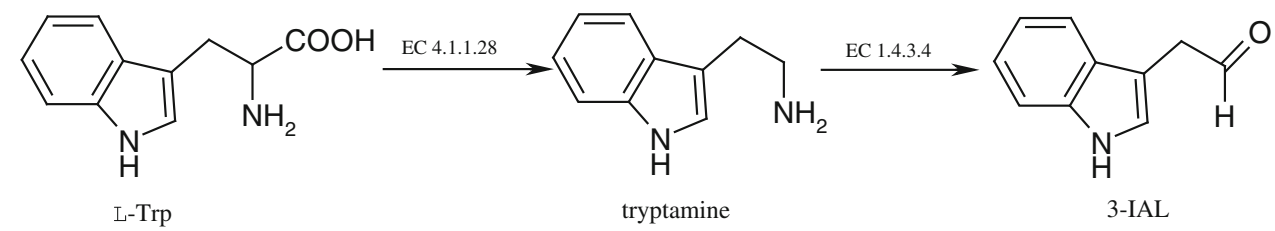

Fig. 2 Enzymatic method of synthesis of isotopologues of tryptamine and its derivatives catalyzed by L-phenylalanine decarboxylase (EC 4.1.1.53)

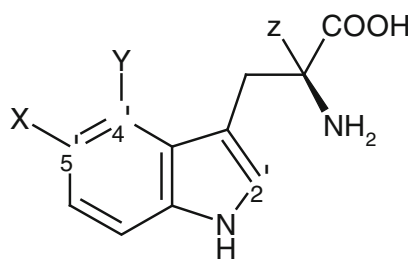

Derivatives or isotopomers of L-Trp

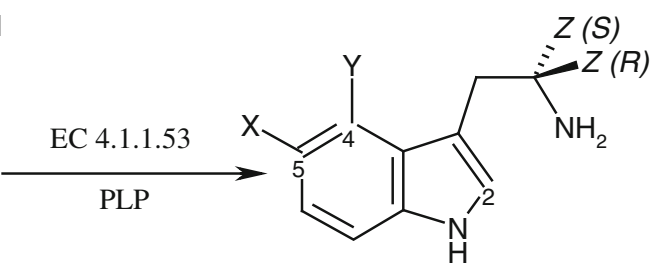

5-F-[(1R)-2 $\left.{ }^{2} \mathrm{H}\right]$-tryptamine $\quad \mathrm{X}=\mathrm{F}, \mathrm{Y}=\mathrm{H}, \mathrm{Z}(R)={ }^{2} \mathrm{H}$ 5-F-[(1R)- $\left.{ }^{3} \mathrm{H}\right]$-tryptamine, $\quad \mathrm{X}=\mathrm{F}, \mathrm{Y}=\mathrm{H}, \mathrm{Z}(R)={ }^{3} \mathrm{H}$ 5-F- $\left[(1 R)-{ }^{2} \mathrm{H} /{ }^{3} \mathrm{H}\right]$-tryptamine, $\mathrm{X}=\mathrm{F}, \mathrm{Y}=\mathrm{H}, \mathrm{Z}(R)={ }^{2} \mathrm{H} /{ }^{3} \mathrm{H}$ 5-Br- $\left[(1 R)-{ }^{2} \mathrm{H}\right]$-tryptamine, $\quad \mathrm{X}=\mathrm{Br}, \mathrm{Y}=\mathrm{H}, \mathrm{Z}(R)={ }^{2} \mathrm{H}$ $\left.[(1 R)]-{ }^{2} \mathrm{H}\right]$-tryptamine $\quad \mathrm{X}=\mathrm{H}, \mathrm{Y}=\mathrm{H}, \mathrm{Z}(R)={ }^{2} \mathrm{H}$ $\left.[(1 R)]-{ }^{3} \mathrm{H}\right]$-tryptamine, $\quad \mathrm{X}=\mathrm{H}, \mathrm{Y}=\mathrm{H}, \mathrm{Z}(R)={ }^{3} \mathrm{H}$ $\left.[(1 R)]-{ }^{2} \mathrm{H} /{ }^{3} \mathrm{H}\right]$-tryptamine, $\quad \mathrm{X}=\mathrm{H}, \mathrm{Y}=\mathrm{H}, \mathrm{Z}(R)={ }^{2} \mathrm{H} /{ }^{3} \mathrm{H}$ $\left[4-{ }^{2} \mathrm{H}\right]$-tryptamine, $\quad \mathrm{X}=\mathrm{H}, \mathrm{Y}={ }^{2} \mathrm{H}, \mathrm{Z}=\mathrm{H}$ $\left[5-{ }^{2} \mathrm{H}\right]$-tryptamine, $\quad \mathrm{X}={ }^{2} \mathrm{H}, \mathrm{Y}=\mathrm{H}, \mathrm{Z}=\mathrm{H}$
From a biological point of view the halogen derivatives of tryptamine are not important for metabolism, nevertheless, in many molecules of biological importance hydrogen can be easy replaced by a halogen, without much changing the activity of these species. The introducing of ${ }^{18} \mathrm{~F},{ }^{79} \mathrm{Br}$, ${ }^{81} \mathrm{Br}$, and ${ }^{131} \mathrm{I}$ in the place of hydrogen atom is widely used for production of radiopharmaceuticals for nuclear medicine and positron emission tomography (PET) [12]. For nuclear medicine it is essential to investigate the metabolism of halogen substituted derivatives of biologically active compounds. Therefore, ${ }^{18}$ F-tryptamine as the potential radiopharmaceuticals [13], is a promising agent for monitoring of abnormal brain states occurring in Parkinson and Alzheimer diseases and schizophrenia, should be a subject of such research.

The studies on the inactive compounds allow to determine the involving of halogenated tryptamines in metabolic reactions. The object of our further study was an investigation whether enzyme AADC effectively catalyzes the oxidative deamination of halogenated derivatives of tryptamine presented in Fig. 1. For study some intrinsic details of mechanism of enzymatic oxidative deamination of halogenated tryptamine and its halogenated derivatives we are going to use the kinetic (KIE) and solvent isotope effects (SIE) methods [14-16].

In this work we presented the enzymatic methods of decarboxylation of L-Trp and its halogenated derivatives for producing tryptamine and its halogen derivatives specifically labeled with deuterium and tritium needed to KIE and SIE studies. The decarboxylation carried out in deuteriated or tritiated incubation media was used to synthesis of isotopomers labeled in the aliphatic chain, i.e., $\left[(1 R)-{ }^{2} \mathrm{H}\right]-,\left[(1 R)-{ }^{3} \mathrm{H}\right]-,\left[(1 R)-{ }^{2} \mathrm{H} /{ }^{3} \mathrm{H}\right]-,, 5-\mathrm{F}-\left[(1 R)-{ }^{2} \mathrm{H}\right]-, 5-\mathrm{F}-$ $\left[(1 R)-{ }^{3} \mathrm{H}\right], 5-\mathrm{F}-\left[(1 R)-{ }^{2} \mathrm{H} /{ }^{3} \mathrm{H}\right]-, \quad 5-\mathrm{Br}-\left[(1 R)-{ }^{2} \mathrm{H}\right]$-tryptamine, and indole ring labeled ones, i.e. $\left[5-{ }^{2} \mathrm{H}\right]-,\left[4-{ }^{2} \mathrm{H}\right]$-tryptamine (Fig. 2).

\section{Experimental}

\section{Materials}

Deuteriated water $\left(99.9 \%{ }^{2} \mathrm{H}\right), 83 \%{ }^{2} \mathrm{H}_{3} \mathrm{PO}_{4} /{ }^{2} \mathrm{H}_{2} \mathrm{O}$ and $30 \% \mathrm{KO}^{2} \mathrm{H} /{ }^{2} \mathrm{H}_{2} \mathrm{O}$ were purchased from Polatom (Poland). Tritiated water $(5 \mathrm{Ci} / \mathrm{mL})$ was from Pharmaceutical Inc., Irvine, CA, USA. The enzyme: L-phenylalanine decarboxylase (EC 4.1.1.53) from Streptococcus faecalis, and coenzyme PLP (pyridoxal-5' -phosphate) were from SigmaAldrich. The chemicals, needed for trial experiments and the enzymatic synthesis, such as L-tryptophan, $5^{\prime}$-fluoro-Ltryptophan, 5'-bromo-L-tryptophan and all other chemicals were from Sigma-Aldrich. TLC plates (DC-Alufolien Kieselgel 60) and silica gel for column chromatography (Kieselgel 60, 0.063-0.200 mm) were from Merck. Liquid scintillation cocktail for aqueous samples was from Ratiszint eco plus (Germany).

Methods

The ${ }^{1} \mathrm{H}$ NMR spectra were recorded in ${ }^{2} \mathrm{H}_{2} \mathrm{O}$ using tetramethylsilane, TMS, as internal standard on a Varian $500 \mathrm{MHz}$ Unity-plus spectrometer. TLC was used for 
identification of substrates and products in the samples taken in the course of enzymatic reactions. As a developing solvent the water solution of acetonitrile was used (acetonitrile:water; 4:1, v/v). Radioactivity of samples were measured using a liquid scintillation counter Perkin Elmer Tri-Carb 2910TR.

Synthesis

\section{Synthesis of $\left[(1 R)-{ }^{2} H\right]$-tryptamine, 1}

1. The isotopologue $\left[(1 R)-{ }^{2} \mathrm{H}\right]$-tryptamine was obtained by one step reaction by enzymatic decarboxylation of L-tryptophan in fully deuteriated incubation medium. The reaction was carried out in an encapped vial with $50 \mathrm{mg}(245 \mu \mathrm{mol}) \mathrm{L}-\mathrm{Trp}$ sample dissolved in $15 \mathrm{~mL}$ of deuteriated $50 \mathrm{mM}$ Tris-DCl buffer (pD 5.9) to which $4 \mathrm{mg}(16 \mu \mathrm{mol})$ of PLP and $50 \mathrm{mg}(1 \mathrm{U})$ of enzyme L-phenylalanine decarboxylase (EC 4.1.1.53) were added. The reaction mixture was incubated at $37^{\circ} \mathrm{C}$ for 2 days and progress of decarboxylation was monitored by TLC. The reaction was quenched by adjusting incubation medium to $\mathrm{pH}>12$ with $30 \%$ $\mathrm{KO}^{2} \mathrm{H} /{ }^{2} \mathrm{H}_{2} \mathrm{O}$. The enzyme was removed by centrifugation, the volume of post-reaction mixture was reduced to $c$. a. $2 \mathrm{~mL}$ by evaporation under reduced pressure at $40{ }^{\circ} \mathrm{C}$, loaded on silica gel column $(100 \times 10 \mathrm{~mm}), \mathbf{1}$ was eluted with acetonitrile solution $\left(\mathrm{CH}_{3} \mathrm{CN}: \mathrm{H}_{2} \mathrm{O} ; 5: 1, \mathrm{v} / \mathrm{v}\right)$, and collected as $1.5 \mathrm{~mL}$ fractions. The presence of $\mathbf{1}$ in the collected fractions was checked by TLC. The fractions containing 1 were combined and evaporated under reduced pressure at $40{ }^{\circ} \mathrm{C}$ and dried under vacuum. As a result $31.7 \mathrm{mg}$ $(196 \mu \mathrm{mol})$ sample of $\left[(1 R)-{ }^{2} \mathrm{H}\right]$-tryptamine was obtained with $80 \%$ chem. yield. The extent of deuterium incorporation (near $100 \%)$ at the $(1 R)$ position of tryptamine was determined by ${ }^{1} \mathrm{H}$ NMR.

\section{Synthesis of $\left[(1 R-)^{3} H\right]$-tryptamine, 2}

2. The $\mathbf{2}$ was obtained by decarboxylation of L-Trp carried out similarly as in case of $\mathbf{1}$ using ten times reduced amounts of reagents $[1 \mathrm{~mL}$ of $50 \mathrm{mM}$ Tris$\mathrm{HCl}$ buffer (pH 5.5), $5 \mathrm{mg}(24.5 \mu \mathrm{mol})$ of L-Trp, $0.8 \mathrm{mg}(3.2 \mu \mathrm{mol})$ of PLP, and $5 \mathrm{mg}(0.05 \mathrm{U})$ of L-phenylalanine decarboxylase]. To this reaction mixture $200 \mu \mathrm{L}$ of tritiated water (total activity of $5.7 \mathrm{GBq}$ ) was added. After 2 days the reaction was quenched by changing $\mathrm{pH}>12$ by adding $30 \% \mathrm{KOH}$. The enzyme was centrifuged off and the mixture was lyophilized three times to remove the excess of tritiated water. The residue was dissolved in $200 \mu \mathrm{L}$ of water and loaded on to silica gel column $(100 \times 10 \mathrm{~mm})$. Product 2 was eluted with acetonitrile solution $\left(\mathrm{CH}_{3} \mathrm{CN}\right.$ : $\mathrm{H}_{2} \mathrm{O}$; $5: 1, \mathrm{v} / \mathrm{v}$ ) and collected as $1.5 \mathrm{~mL}$ fractions. From each fraction $10 \mu \mathrm{L}$ samples was taken for radioassay. The fractions containing radioactive $\mathbf{2}$ were combined, lyophilized and dried under vacuum. As a results a sample of $3.1 \mathrm{mg}(19.1 \mu \mathrm{mol})$ of $\mathbf{2}(78 \%$ chem. yield $)$ was obtained with a total activity of $3.7 \times 10^{4} \mathrm{~Bq}$ (specific activity of $1.49 \mathrm{MBq} / \mathrm{mmol}$ ).

\section{Synthesis of $\left[(1 R)-{ }^{2} H \beta^{\beta} H\right]$-tryptamine, 3}

3. This isotopomer, doubly labeled with deuterium and tritium was obtained using the same procedure and amounts of reagents as in the case of $2\left[(1 R){ }^{3} \mathrm{H}\right]-$ tryptamine. The decarboxylation of $5 \mathrm{mg}(24.5 \mu \mathrm{mol})$ L-Trp was carried out in fully deuteriated $50 \mathrm{mM}$ TrisDCl buffer (pD 5.9) to which $200 \mu \mathrm{L}$ of ${ }^{2} \mathrm{H}^{3} \mathrm{HO}$ with total activity $5.7 \mathrm{~GB}$ was added. As a result $3 \mathrm{mg}$ $(18.6 \mu \mathrm{mol})$ of doubly labeled $\left[(1 R)-{ }^{2} \mathrm{H} /{ }^{3} \mathrm{H}\right]$-tryptamine was obtained with a total activity of $3 \mathrm{kBq}$ (specific activity of $1.28 \times 10^{5} \mathrm{~Bq} / \mathrm{mmol}$ ) and $76 \%$ chem. yield.

\section{Synthesis of 5-Br-[(1R)- $\left.{ }^{2} H\right]-$ tryptamine, 4}

4. The sample of 5'-bromo-D, L-Trp (50 mg, $176.5 \mu \mathrm{mol})$ was dissolved in $11 \mathrm{~mL}$ of deuteriated $50 \mathrm{mM}$ Tris$\mathrm{DCl}$ buffer (pD 5.9) to which $2 \mathrm{mg}(8 \mu \mathrm{mol})$ of PLP and $26.5 \mathrm{mg}$ (1 U) L-phenylalanine decarboxylase were added. The reaction mixture was incubated at $37{ }^{\circ} \mathrm{C}$ for 2 days. The separation and purification of product were the same as in case of isotopomer $\mathbf{1}$. Finally, a $7.1 \mathrm{mg}(29.7 \mu \mathrm{mol})$ sample of 4 was obtained ( $14.2 \%$ chem. yield). The extent of deuterium incorporation (near $100 \%)$ at the $(I R)$ position of 4 was determined by ${ }^{1} \mathrm{H}$ NMR spectrum.

Synthesis of $5-F-\left[(1 R)-{ }^{2} H\right]-$ tryptamine, 5

5. The experimental procedure was similar as in the case of $\mathbf{1}$. The sample of $5^{\prime}$-fluoro-L-Trp $(25 \mathrm{mg}, 112 \mu \mathrm{mol})$ was dissolved in $7 \mathrm{~mL}$ of deuteriated $50 \mathrm{mM}$ Tris-DCl buffer (pD 5.9) to which $1 \mathrm{mg}(4 \mu \mathrm{mol})$ of PLP and $26.5 \mathrm{mg}(1 \mathrm{U})$ of L-phenylalanine decarboxylase were added. As a result a $18 \mathrm{mg}(101 \mu \mathrm{mol})$ sample of $\mathbf{5}$ was obtained with $90 \%$ chem. yield. The extent of deuterium incorporation (near $100 \%$ ) at the $(I R)$ position of 5 was determined by ${ }^{1} \mathrm{H}$ NMR spectrum. 
Synthesis of 5-F-[(1R)- $\left.{ }^{3} H\right]$-tryptamine, 6

6. The $5.8 \mathrm{mg}(26.1 \mu \mathrm{mol})$ sample of $\left[5^{\prime}-\mathrm{F}\right]-\mathrm{L}-\mathrm{Trp}$ was dissolved in $1.2 \mathrm{~mL}$ of $50 \mathrm{mM}$ Tris- $\mathrm{HCl}$ buffer ( $\mathrm{pH} 5.5$ ) to which $0.6 \mathrm{mg}(2.43 \mu \mathrm{mol})$ of PLP and $5.2 \mathrm{mg}(1 \mathrm{U})$ of enzyme L-phenylalanine decarboxylase were added. To this incubation medium $300 \mu \mathrm{L}$ of tritiated water (total activity of $8.6 \mathrm{GBq}$ ) was introduced. The method of separation and purification of product was the same as in the case of 2 . As the results $3.9 \mathrm{mg}(21.8 \mu \mathrm{mol})$ of $\mathbf{6}$ was obtained (84\% chem. yield) with total activity $3.1 \times 10^{4} \mathrm{~Bq}$ (specific activity of $1.24 \mathrm{MBq} / \mathrm{mmol}$ ).

\section{Synthesis of 5-F-[(1R)- $\left.{ }^{2} H{ }^{3} H\right]$-tryptamine, 7}

7. This product was obtained in the same manner as described in the case of 3 . The sample of $5.5 \mathrm{mg}$ $(24.7 \mu \mathrm{mol})\left[5^{\prime}-\mathrm{F}\right]-\mathrm{L}-\mathrm{Trp}$ was dissolved in $1.4 \mathrm{~mL}$ of $50 \mathrm{mM}$ Tris-DCl buffer, $\mathrm{pD} 5.9$, to which $0.6 \mathrm{mg}$ $(2.43 \mu \mathrm{mol})$ of PLP, $5.2 \mathrm{mg}$ (1 U) of L-phenylalanine decarboxylase, and $350 \mu \mathrm{L}$ of ${ }^{2} \mathrm{H}^{3} \mathrm{HO}$ (total activity of $10 \mathrm{GBq})$ were added. Finally, a $3.6 \mathrm{mg}(20.3 \mu \mathrm{mol})$ sample of 7 was afforded ( $82 \%$ chem. yield) with total activity $8.7 \times 10^{4} \mathrm{~Bq}$ (specific activity of $3.56 \mathrm{MBq} / \mathrm{mmol})$.

\section{Synthesis of $\left[4-^{2} H\right]$-tryptamine, 8}

8. The sample of $10 \mathrm{mg}(48.8 \mu \mathrm{mol})$ of $\left[4^{\prime}-{ }^{2} \mathrm{H}\right]-\mathrm{L}-\mathrm{Trp}$, obtained as described earlier [17] was dissolved in $1 \mathrm{~mL}$ $50 \mathrm{mM}$ Tris- $\mathrm{HCl}$ buffer (pH 5.5) to which $2 \mathrm{mg}$ $(8 \mu \mathrm{mol})$ of PLP and $10 \mathrm{mg}(1 \mathrm{U})$ of L-phenylalanine decarboxylase were added. The experimental protocol of synthesis, separation, and purification of $\mathbf{8}$ was the same as described for derivative 1. As a result a $6.4 \mathrm{mg}$ $(39.8 \mu \mathrm{mol})$ sample of $\mathbf{8}$ was obtained with $82 \%$ chem. yield and $73 \%$ of deuterium enrichment at the $4^{\prime}$-indole ring position determined by ${ }^{1} \mathrm{H}$ NMR.

\section{Synthesis of $\left[5-{ }^{2} H\right]$-tryptamine, 9}

9. The compound $\mathbf{9}$ was obtained by the same protocol as in case of $\mathbf{8}$ using as a substrate $\left[5^{\prime}-{ }^{2} \mathrm{H}\right]$-L-Trp synthesized according modified procedures described earlier [18]. The sample of $3 \mathrm{mg}(14.6 \mu \mathrm{mol})$ of $\left[5^{\prime}-{ }^{2} \mathrm{H}\right]-\mathrm{L}-\mathrm{Trp}$ (100\% ${ }^{2} \mathrm{H}$ enrichment) was dissolved in $50 \mathrm{mM}$ Tris$\mathrm{HCl}$ buffer $\mathrm{pH} 5.5$ to which $0.6 \mathrm{mg}(2.43 \mu \mathrm{mol})$ of PLP and $5.2 \mathrm{mg}(1 \mathrm{U})$ L-phenylalanine decarboxylase were added. As a result a $1.8 \mathrm{mg}(11.4 \mu \mathrm{mol})$ of 9 was obtained (78\% chem. yield) with $100 \%$ of deuterium enrichment.

\section{Results and discussion}

Generally, all nine isotopomers of tryptamine and its halogen derivatives were synthesized in course of enzymatic decarboxylation, Fig. 1, of appropriate derivatives of L-tryptophan. For this reaction instead of the enzyme aromatic L-ADDC (EC 4.1.1.28) L-phenylalanine decarboxylase (EC 4.1.1.53) from Streptococcus faecalis [14] (having the similar properties as ADDC) was used. Previous studies [19, 20] has strongly documented that enzymatic decarboxylation of $\alpha$-L-amino acids undergoes together with the replacement of carboxyl group by solvent proton (deuteron/triton) with retention of configuration at the $\alpha$-carbon (Fig. 3).

Therefore, the enzymatic decarboxylation of appropriated derivative of L-Trp carried out in fully deuteriated or tritiated medium produces corresponding tryptamine labeled with deuterium or tritium in configuration $(1 R)$. Introduction of one deuterium (or tritium) atom from incubation medium to the newly generated tryptamine and preserving the configuration at the carbon atom in the $\alpha$ position leads to obtain $R$-isotopologues of tryptamines [19-22].

The tritium labeled compounds 2 and $\mathbf{6}$, i.e., $\left[(1 R)-{ }^{3} \mathrm{H}\right]-$, and $5-\mathrm{F}-\left[(1 R)-{ }^{3} \mathrm{H}\right]-$ tryptamine were synthesized by enzymatic decarboxylation of L-Trp and [5'-F]-L-Trp carried out in tritiated $\left({ }^{1} \mathrm{H}^{3} \mathrm{HO}\right)$ Tris- $\mathrm{HCl}$ buffered medium, pH 5.5 (at this $\mathrm{pH}$ value the enzyme L-phenylalanine decarboxylase shows the maximum activity). The deuteriated compounds 1, 4, and 5, i.e., $\left[(1 R)-{ }^{2} \mathrm{H}\right]-, 5-\mathrm{Br}-\left[(1 R)-{ }^{2} \mathrm{H}\right]-$ and $5-\mathrm{F}-$ $\left[(1 R)-{ }^{2} \mathrm{H}\right]$-tryptamine were obtained by decarboxylation of L-Trp, [5'-Br]-D, L-Trp, and [5'-F]-L-Trp, respectively, in fully deuteriated Tris-DCl buffer, $\mathrm{pD}$ 5.9. The compounds 3 and 7 doubly labeled with deuterium and tritium, i.e., $\left[(1 R)-{ }^{2} \mathrm{H} /{ }^{3} \mathrm{H}\right]-$ and $5-\mathrm{F}-\left[(1 R)-{ }^{2} \mathrm{H} /{ }^{3} \mathrm{H}\right]$-tryptamine were synthesized in fully deuteriated Tris-DCl buffer, $\mathrm{pD} 5.9$, to which tritiated water was added. In the case when the synthesis was carried out in fully deuteriated incubation medium its $\mathrm{pD}$ was corrected to 5.9 value due to higher $\mathrm{pK}$ $\left(\mathrm{D}_{2} \mathrm{O}\right)$ [23]. In the case of deuteriated media all substrates for decarboxylation reaction were dissolved in almost entirely deuteriated $50 \mathrm{mM}$ Tris-DCl buffer (394 mg, $2.5 \mathrm{mmol}$ ) of Tris- $\mathrm{HCl}$ were dissolved in $50 \mathrm{~mL}$ of $\mathrm{D}_{2} \mathrm{O}$; and calculated fraction of $\mathrm{H}^{+} / \mathrm{D}^{+}$ions in this way prepared incubation medium was equal to 0.0005 ).

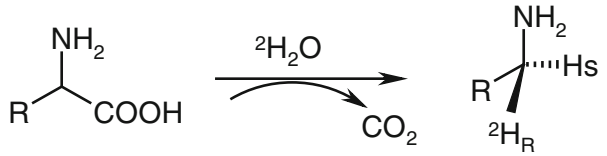

Fig. 3 The stereochemistry of the enzymatic decarboxylation of $\alpha$-amino acids 
The compound $\mathbf{8}$, i.e., $\left[4{ }^{2} \mathrm{H}\right]$-tryptamine, labeled with deuterium in the 4-position of indole ring was synthesized by decarboxylation of $\left[4^{\prime}{ }^{2} \mathrm{H}\right]-\mathrm{L}-\mathrm{Trp}$ which was obtained by ${ }^{1} \mathrm{H} /{ }^{2} \mathrm{H}$ isotope exchange according the procedure described earlier [24, 25]. The exchange was catalyzed with UV light produced by a $250 \mathrm{~W}$ mercury lamp. The sample of L-Trp dissolved in ${ }^{2} \mathrm{H}_{2} \mathrm{O}$ was irradiated in a sealed and outgassed glass ampoule. The ${ }^{1} \mathrm{H}$ NMR spectrum showed that deuterium enrichment at the $4^{\prime}$ position of L-Trp was around $73 \%$.

The indole ring labeled compound 9, i.e. $\left[5-{ }^{2} \mathrm{H}\right]$-tryptamine was obtained by decarboxylation of $\left[5^{\prime}-{ }^{2} \mathrm{H}\right]-\mathrm{L}-\mathrm{Trp}$ synthesized according earlier described procedures [18, 25]. This intermediate $\left[5^{\prime}-{ }^{2} \mathrm{H}\right]-\mathrm{L}-\mathrm{Trp}$ was obtained in two step synthesis: first 5-bromoindole was reduced by sodium borodeuteride, $\mathrm{NaB}^{2} \mathrm{H}_{4}$, to[5- $\left.{ }^{2} \mathrm{H}\right]$-indole [25], which in next step, catalyzed by enzyme tryptophanase (L-tryptophan indole-lyase EC 4.1.99.1), was coupled with $S$ methyl-L-cysteine giving $\left[5^{\prime}-{ }^{2} \mathrm{H}\right]-\mathrm{L}-\mathrm{Trp}$ [18] (Near $100 \%$ deuterium incorporation in the $5^{\prime}$-position by ${ }^{1} \mathrm{H}$ NMR spectrum). The enzymatic decarboxylations of $\left[4^{\prime}-{ }^{2} \mathrm{H}\right]-$, and $\left[5^{\prime}-{ }^{2} \mathrm{H}\right]-\mathrm{L}-\mathrm{Trp}$, leading to 8 and $\mathbf{9}$ were carried out in $50 \mathrm{mM}$ Tris- $\mathrm{HCl}$ buffer, $\mathrm{pH}$ 5.5.

The derivative 4 , i.e. 5 - $\mathrm{Br}-\left[(1 R)^{-2} \mathrm{H}\right]$-tryptamine was obtained with relatively low chemical yield (about $15 \%$ ) as for decarboxylation reaction. It is possible that, this enzyme is less effective catalyst for decarboxylation of [5'$\mathrm{Br}$-L-Trp with such large ring substituent as bromine. For this reason, we made no attempts to synthesize its isotopologue, i.e. tritiated 5-Br-[(1R)- $\left.{ }^{3} \mathrm{H}\right]$-tryptamine.

The extent of deuterium incorporation in the $(1 R)$ position of tryptamines was determined by measuring the signal integration derived from the $\alpha$-protons in ${ }^{1} \mathrm{H}$ NMR spectrum. In the same manner the deuterium enrichment in the $4^{\prime}-$ and $5^{\prime}$-positions of intermediates $\left[4^{\prime}{ }_{-}^{2} \mathrm{H}\right]-$, and $\left[5^{\prime}-{ }^{2} \mathrm{H}\right]-\mathrm{L}-\mathrm{Trp}$ was identified.

Acknowledgments This work was supported by Grant BST 501/86DSM-102400.

Open Access This article is distributed under the terms of the Creative Commons Attribution License which permits any use, distribution, and reproduction in any medium, provided the original author(s) and the source are credited.

\section{References}

1. Kema Ido P, De Vries Elisabeth GE, Muskiet Frits AJ (2000) Clinical chemistry of serotonin and metabolites. J Chromatogr B 747:33-48

2. Itoh MT, Ishizuka B, Kuribayashi Y, Amemiya A, Sumi Y (1999) Melatonin, its precursors, and synthesizing enzyme activities in the human ovary. Mol Reprod 5:402-408
3. Jacob MS, Presti DE (2005) Endogenous psychoactive tryptamines reconsidered: an anxiolytic role for dimethyltryptamine. Med Hypoth 64:930-937

4. Brandt SD, Martins CPB (2010) Analytical methods for psychoactive $N, N$-dialkylated tryptamines. TrAC 29:858-869

5. Maximino C (2012) Serotonin and anxiety, serotonin in the nervous system of vertebrates. Springer, New York

6. Hocck DR, Floss HG (1981) Preparation of stereospecifically $\alpha$ and $\beta$-tritiated tryptamine and the stereochemistry of aromatic Lamino acid decarboxylase. J Nat Prod 44:759-762

7. Slominski A, Semak I, Pisarchik A, Sweatman T, Szczesniewski A, Wortsman J (2002) Conversion of L-tryptophan to serotonin and melatonin in human melanoma cells. FEBS Lett 511:102-106

8. Lovenberg W, Weissbach H, Underfriend S (1962) Aromatic Lamino acid decarboxylase. J Biol Chem 237:89-93

9. Gale EF (1945) Studies on bacterial amino-acid decarboxylases. Biochem J 39:46-52

10. Nagai T, Hamada M, Kai N, Tanoue Y, Nagayama F (1995) Purification and properties of aromatic L-amino acid decarboxylase from liver of skipjack tuna. Comp Biochem Physiol 112B:265-270

11. Nishigaki I, Ichinose H, Tamai K, Nagatsu T (1988) Purification of aromatic L-amino acid decarboxylase from bovine brain with a monoclonal antibody. Biochem J 252:331-335

12. Bomanji JB, Costa DC, Ell PJ (2001) Clinical role of positron emission tomography in oncology. Lancet Oncol 2:157-164

13. Pacak K, Eisenhofer G, Carrasquillo JA, Chen CC, Sheng-Ting $\mathrm{Li}$, Goldstein DS (2001) 6-[ $\left[{ }^{18} \mathrm{~F}\right]$ fluorodopamine positron emission tomographic (PET) scanning for diagnostic localization of pheochromocytoma. Hypertension 38:6-8

14. Wigley LJ, Mantle PG, Perry DA (2006) Natural and directed biosynthesis of communesin alkaloids. Phytochemistry 67:561-569

15. Huskey WP (1991) Origins and interpretations of heavy-atom isotope effects. In: Cook PF (ed) Enzyme mechanism from isotope effects. CRC, Boca Raton, pp 37-73

16. Schowen RI (1972) Mechanistic deductions from solvent isotope effects. Prog Phys Org Chem 9:275-329

17. Saito I, Sugiyama H, Yamamoto A, Muramatsu S, Matsuura T (1984) Photochemical hydrogen-deuterium exchange reaction of tryptophan. The role in nonradioative decay of singlet tryptophan. J Am Chem Soc 106:4286-4287

18. Kiick DM, Phillips RS (1988) Mechanistic deductions from multiple kinetic and solvent deuterium isotope effect and $\mathrm{pH}$ studies of pyridoxal phosphate dependent carbon-carbon lyases: Escherichia coli tryptophan indole-lyase. Biochemistry 27:7339-7344

19. Belleau B, Burba J (1960) The stereochemistry of the enzymic decarboxylation of amino acids. JACS 82:5751-5752

20. Battersby R, Scott A, Staunton J (1990) Studies of enzymemediated reactions. Stereochemical course of the formation of 5-hydroxytryptamine (serotonin) by decarboxylation of (2S)-5hydroxytryptophan with the aromatic L-amino acid decarboxylase (EC 4.1.1.28) from hog kidney. Tetrahedron 46:4685-4696

21. Vederas JC, Reingold ID, Sellers HW (1979) Stereospecificity of sodium borohydride reduction of tyrosine decarboxylase from streptococcus faecalis. J Biol Chem 254:5053-5057

22. Chang GW, Snell EE (1968) Histidine decarboxylase of Lactobacillus 30a. II. Purification, substrate specificity, and stereospecificity. Biochemistry 7:2005-2012

23. Gary R, Bates RG, Robinson RA (1964) Second dissociation constant of deuteriophosphoric acid in deuterium oxide from 5 to $50{ }^{\circ} \mathrm{C}$ : standardization of pD scale. J Phys Chem 68:3806-3809

24. Winnicka E, Kańska M (2009) Synthesis of L-tryptophan labeled with hydrogen isotopes in the indole ring. J Radioanal Nucl Chem 279:675-678

25. Bosin TR, Raymond MG, Buckpitt AR (1973) A site-specific method for deuteration: reduction of aryl halides with sodium borodeuteride and palladium chloride. Tetrahedron Lett 14:4699-4700 